\title{
GENTRIFICATION IN ISTANBUL: GENERATING INSIGHTS THROUGH PHOTOGRAPHY
}

\author{
Çeyiz MAKAL FAIRCLOUGH*
}

\begin{abstract}
Gentrification is a process that describes the regeneration of run-down districts of a city; people from high income groups move into an area and, over time, the original residents move out. This process can be seen in Istanbul during the 1980 s when some buildings in the central areas of the city were restored and are now used by people of upper social classes, income groups, cultures and lifestyles. Slum clearance programmes and the building of new apartment blocks has resulted in the gentrification of many parts of the city. This study focuses on one district of Istanbul that has been affected by this type of gentrification. The purpose of the study was to explore what role photography might have in developing an understanding of the gentrification process. The research included a photo-elicitation exercise with some of the residents to understand the effect of gentrification on their lives. This paper outlines the context around gentrification, the methodology employed by the researcher and the findings from the study. The study concludes that visual methodologies can provide valuable data, giving a better understanding of the process and impact of gentrification in Turkey.
\end{abstract}

Keywords: gentrification, photography, visual methodologies, photo-elicitation.

* Lecturer/PhD, Beykent University, Faculty of Fine Arts 


\title{
ISTANBUL'DA KENTSEL DÖNÜŞÜM: FOTOĞRAF ÜZERINDEN KAVRAYIŞ GELIŞTIRME
}

\author{
Çeyiz MAKAL FAIRCLOUGH*
}

\begin{abstract}
Özet
Kentsel dönüşüm bir şehrin gözden düşmekte olan bölgelerinin yenilenmesini açıklayan bir süreçtir; yüksek gelire sahip gruplar bölgeye yerleştirilir ve zaman ilerledikçe ilk etapta bölgede yaşayan nüfus o bölgeden taşınır. Bu süreç isstanbul'da 1980'lerde restore edilmiş merkezi bölgelerdeki bazı binalarda görülebilmektedir ve bu alanlar şimdilerde yüksek gelirli, kültürlü ve belirli bir yaşam kalitesine sahip üst düzey sosyal sınıflar tarafından kullanılmaktadır. Gecekondu yıkma programları ve yeni apartman bloklarının inşa edilmesi, şehrin birçok bölümünde gerçekleştirilen yeni kentsel dönüşümün sonucudur. Bu çalışma, İstanbul'da bu tip bir kentsel dönüşüm geçirmiş olan bir bölgeyi ele almaktadır. Çalışmanın amacı, gelişen kentsel dönüşüm sürecini anlamada fotoğrafın nasıl bir rolü olduğunu araştırmaktır. Araştırmaya kentsel dönüşümün bazı bölge sakinlerinin hayatlarında nasıl bir etki yarattığını anlamak için fotoğrafik uyarım metodu dâhil edilmiştir. Bu çalışmada, kentsel dönüşüm bağlamında, araştırmacı tarafından kullanılan metodoloji ve araştırmadan elde edilen bulgular özetlenmektedir. Çalışma, görsel metodolojilerin değerli veriler sağlayabildiği ve böylece Türkiye'deki kentsel dönüşüm süreci ile etkilerinin daha iyi kavranabileceğinin sonucuna varmaktadır.
\end{abstract}

Anahtar Kelimeler: kentsel dönüşüm, fotoğrafçılık, görsel metodolojiler, fotoğrafik uyarım.

* Doktor Öğretim Üyesi, Beykent Üniversitesi, Güzel Sanatlar Fakültesi 


\section{Introduction}

Gentrification is a term first used by the British sociologist Ruth Glass in 1964 and was applied to what was happening in cities in UK and US in the 1950s and 1960s; the regeneration of run-down districts of the city by the middle classes resulting in the working-class residents being displaced. Glass (1964: xix) drew attention to the social consequences of this process: "Once this process of 'gentrification' starts in a district it goes on rapidly until all or most of the original working-class occupiers are displaced and the social character of the district is changed". Subsequent definitions of gentrification tended to relate back to Glass's original description: "By gentrification I mean the process by which working class residential neighbourhoods are rehabilitated by middle class homebuyers, landlords and professional developers" (Smith, 1982:139).

There is however a different type of gentrification that is not about rehabilitation of existing property at all but instead can be described as new-build gentrification. Davidson and Lees (2005) described a new build type of gentrification that involved reclaimed industrial land and so did not result in direct displacement. In Turkey, however, there is a further variation on this type of gentrification. There is new build on reclaimed industrial land but there is also a process of slum clearance to generate space for luxury apartments which does involve direct displacement. This process has been described as follows (Islam, 2005: 125):

High-rise apartment blocks are constructed on the land once occupied by one or two storey squatter settlements, resulting in both the displacement and replacement of the squatter population by middle and upper middle-income groups. These renewal projects involve the construction of luxury apartment blocks

He further points out that whilst squatter owners may be reimbursed the squatter renters have no rights: "Squatter renters are not regarded as the participants of the project and are displaced involuntarily" (Islam, 2005: 125).

Various sociological studies have been conducted on gentrification in Turkey. Uzun (2003) for example, conducted a detailed and insightful sociological study of gentrification in Istanbul and Ankara, drawing on three case studies. One of these case studies related to an urban renewal project in Ankara in a squatter settlement. The methodologies used for that study involved a combination of standard qualitative and quantitative social science research methodologies. Uzun (2003) refers to three methods used to collect data, the first was the collection and analysis of written and visual materials related to the survey area, the second involved the interviewing of key informants and the third was a sample survey. Photographs appear in the published report to provide additional context.

The project undertaken by the author focuses on the type of gentrification described by Islam (2005) above in one district of Istanbul and is similar in some respects to the Ankara case study provided by Uzun (2003). There is

\section{$100 \mid$ ETKíleşim | Yıl2|Sayı 3 | Nisan 2019}


large-scale construction taking place (see Figure 1 below) on land previously occupied by squatter settlements. Most of the long-term residents of this area come originally from the Black Sea region of Turkey.

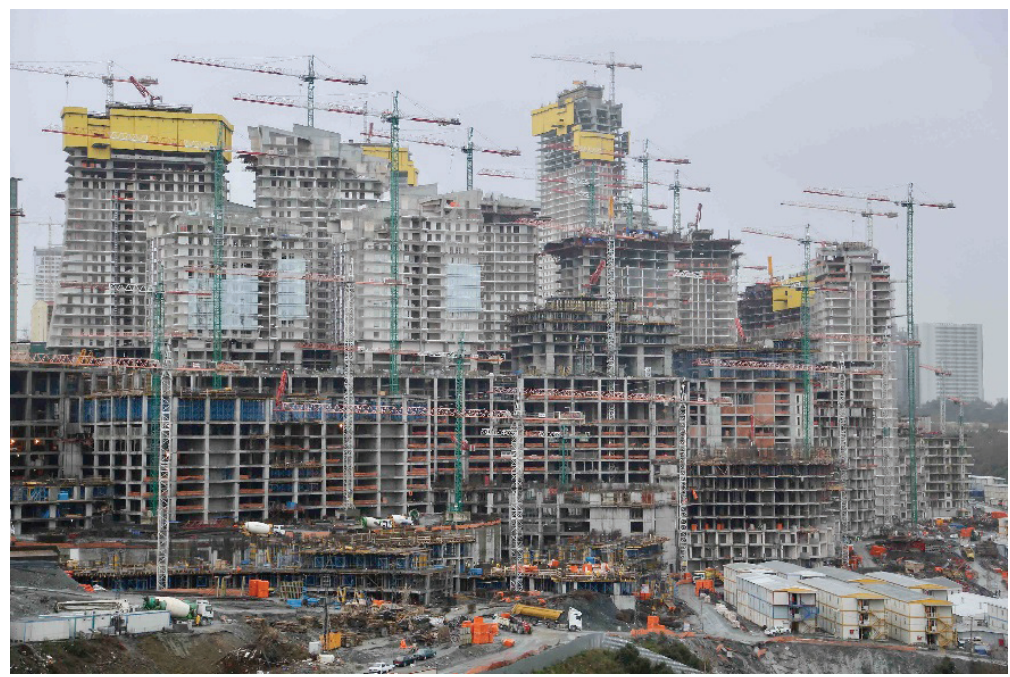

Figure 1

This project differs from other studies on gentrification in Turkey however as photography was an integral feature of the research methodology at each stage of the project. This paper sets out the research objectives and methodology, the three stages of fieldwork and some of the challenges encountered and the findings and conclusions from the project. It references some published findings on the first two stages of the project but focuses particularly on the final stage of research, the photo-elicitation, and what the research says about gentrification in Istanbul.

\section{Aim, Objectives and Methodology}

As an artist and photographer, the author was inspired to document a rapidly changing landscape and to find out whether photography might help to provide some insights into the process of gentrification described above by Islam (2005) and its social consequences.

The aim and principle research objective for this project was to explore what role photography might have in developing an understanding of the gentrification process in Istanbul and its effects on resident communities. Gentrification is a complex socio-economic phenomenon. This project explores whether photography can do more than just add context and a backdrop and instead form an integral part of a research project into gentrification. Can a photographer help to reveal aspects of gentrification which would not be possible within a non-visual research approach? 
Other objectives were to:

- Document the transformation of a city district and a community in transition;

- Gain a deeper understanding of the Black Sea community in Istanbul and their perspective on the social impact of gentrification;

- Understand more about how the different communities interact.

There were three distinct and interconnected stages to this project, each with its own specific methodological approach. Underpinning the methodology however was a reflexive approach that acknowledged the role of the researcher within the process. As Rose (2012: 183) states: "(...) reflexivity is an attempt to resist the universalising claims of academic knowledge, and to insist that academic knowledge, like all other knowledges, is situated and partial". Pink (2013: 3) refers to "(...) the centrality of subjectivity in the production of knowledge" and indicates that visual methodologies are no more subjective than written texts. The researcher was not attempting to uncover objective facts about the process of gentrification but instead recognised and reflected upon her role in the process and the fundamental subjectivity inherent within qualitative research.

The researcher also adopted a rigorous ethical approach to ensure that no harm could come to the participants in the project. The most important feature of this approach, which formed an integral aspect of the whole methodology, was the principle of collaboration. This is an approach recommended by Pink (2013: 63): "However, anxiety and harm to participants might also be limited and at best avoided by taking a collaborative approach to visual research".

\section{Stage 1: getting started}

Fairclough (2017) sets out the origins of this research project including the importance of getting to understand the locality by spending a lot of time within the community and making local contacts. The researcher worked alongside the community that she was studying for over three years. By living and working in the community, the researcher became a known and recognisable figure and was able to observe the life of the community in the shops, markets and restaurants.

Hammersley and Atkinson (1995) describe four possible roles for a researcher conducting social science fieldwork: complete participant, participant as observer, observer as participant and complete observer. The participant as observer, the role adopted by the author for this project, is characterized by "comparative involvement: subjectivity and sympathy" (1995: 104).

The process of gaining access, establishing trust and building rapport was critical to the success of this project. Given the closed nature of this community, this required considerable tact and sensitivity. Prosser and Schwartz (1998)

\section{2 | ETKíleşim | Yıl2|Sayı 3 | Nisan 2019}


emphasise the importance of these early stages in the process and the added complexity arising from using visual methodologies: "All qualitative researchers confront the process of establishing rapport with subjects, but cameras present additional complexities for subjects and researchers alike" (1998: 106).

Pink (2013) points to the potential value in using the camera to help build rapport with project participants but acknowledges that it may not always be the best approach to start taking photographs straightaway: "In some contexts photographing can help to initiate the research process and to establish relationships with participants, while in others it may be more appropriate to wait several months before beginning to photograph..." (2013: 78).

For this project, the researcher made contact initially with an elderly woman who was a respected figure in the community. She acted as a gatekeeper and through her she got to know other members of the community. By taking the time to establish these relationships, before taking any photographs of individuals, it was possible for the researcher to establish a rapport which subsequently made taking photographs much easier. It also provided her with access that she would otherwise not have had.

It was also the case, however, that when the researcher did introduce the camera into her interactions with individuals who helped her to build rapport with members of the community. When taking photographs in the streets, the camera prompted conversations. Prosser and Schwartz (1998: 107) comment on the importance of these early interactions involving the camera:

Whatever the opening, whether discussions of our activities, our equipment, or the weather, these first encounters with community members can (and should) be used to lay the groundwork for future data collection. Our identity as friend or foe is often established during these initial exchanges.

In these early exchanges some individuals, especially men, were suspicious of motivations, thinking that perhaps the researcher was a journalist. She was able to address these concerns by saying that she knew women from the local community. These interactions quickly became very positive and individuals spoke about how their locality was changing and their hopes and fears for the future. In these early exchanges the researcher did not record the conversations with members of the local community. This would potentially have aroused suspicions. Instead, these early exchanges helped to shape thinking about the direction of the research and laid the foundations by establishing trust within the community.

\section{Stage 2: photo-documentation and data analysis}

The researcher realised from the early interactions with the local community that the process of gentrification that was rapidly taking place was having a profound impact on the local community. Simply taking photographs of 
what seemed interesting would not enable her to gain a deeper understanding of what was happening. She needed a structure in order to explore the social impacts of gentrification. She adopted therefore the principles of photo-documentation, which Rose (2012: 301) describes as follows:

Photo-documentation is a method that assumes photographs are accurate records of what was in front of the camera when its shutter snapped (...) and takes photographs in a systematic way in order to provide data which the researcher then analyses.

Inspired by the methodology of Suchar (1997), who studied the gentrification of Lincoln Park in Chicago through photo-documentation, the researcher established her own guiding questions to help focus attention and adapted these as the project evolved. The initial questions were:

- Where do members of this community live, work, shop, eat and socialise?

- To what extent do members of this community mix with the other communities in the neighbourhood?

Also inspired by Suchar, the researcher identified connections between different images to help illustrate aspects of the gentrification process. Fairclough (2018) referenced this stage of the project and pointed out that the images of the shops built by the original Black Sea community, compared to the shops built by the new middle-class residents, highlighted the sharp division between the communities. Fairclough (2018) also pointed out that the building of new dry cleaners and groceries sent a signal that an infrastructure for the new community was being developed and anticipated the likelihood of the existing infrastructure disappearing as more land is taken over by the developers.

Whilst adopting the basic principles of photo-documentation, which helped to provide a framework for this stage of the study, the researcher recognised that the quasi-scientific approach suggested by Rose (2012) above and implemented by Suchar (1997) would not necessarily provide her with the results she was looking for. She adopted a more reflexive approach, recognising the inherent subjectivity of the photographs she was taking.

To help with the analysis of the images the researcher developed a 'visual diary'. The process of selecting images and writing up notes on them enabled the researcher to analyse whether the photographs were helping to address the initial questions and stimulated ideas about how to take the project forward. Keeping a visual diary helped to maintain a degree of critical distance whilst acknowledging the role of the researcher within the process:

The notion of photographs as visual diary reintroduces the researcher and the qualities of the medium into the research process. That is, a diary is a selfreflexive and media-literate chronicle of the researcher's entry, participation in, and departure from, the field. The images generated within this paradigm are acknowledged to be the unique result of the interaction of a certain researcher

\section{4| ETKíleşim | Yıl2|Sayı3| Nisan 2019}


with a specific population using a particular medium at a precise moment in space and time (Prosser and Schwartz, 1998: 108).

Prosser and Schwartz (1998) contrast the 'visual diary' with the 'visual record', the purpose of which is to systematically record visual details for ethnographic or other forms of study.

The outcome of this stage of the research was a collection of photographs that explored questions around gentrification. The photographs helped to illustrate the specific type of gentrification that was taking place, a process of clearing areas and building new properties. The working-class residents from the Black Sea region were living and working in very close proximity to the newly arrived middle-class residents but the images suggested that there was probably little contact between them. The situation of the slum area so close to the new buildings in Figure 2 is striking.

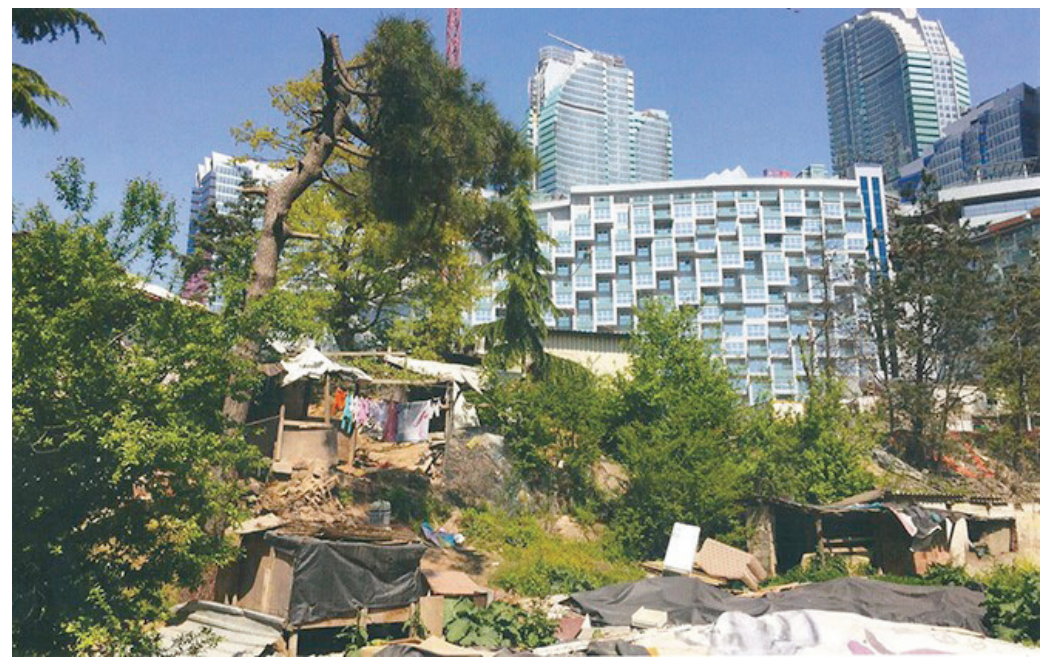

Figure 2

The photographs suggested to the researcher that the residents might be feeling anxious about the process of gentrification and concerned about whether they would be able to retain their culture and way of life. She decided therefore to develop the project further in order to explore in greater depth what residents thought and felt about their community and what was happening to it. The images also prompted her to explore the gentrification process from the perspective of the new middle-class residents.

\section{Stage 3: photo-elicitation}

The researcher decided that the best way to dig deeper into what people felt about gentrification was through a methodology called photo-elicitation. 
Harper (2012) describes photo-elicitation as follows: "The process involves inserting a photograph (or other image, though most are photos), into the research interview" (2012: 156). He differentiates photo-elicitation, which usually involves researcher generated images, from photo-voice, which usually involves images produced by the participants of the research. In this instance, the researcher chose to use images that she had generated from the previous stage of the project. The rationale for this approach was that she would be able to test out assumptions that she had drawn from the images. In addition, the researcher wanted to contrast how people from different communities responded to the same images. Harper goes on to describe the process as follows: "Usually the researcher asks the subject to identify, explain or reflect on elements in a photograph that the researcher has made during the research process..." (2012: 157). This description accurately reflects the approach adopted by the researcher for this project.

Photo-elicitation as a methodology was established by John Collier. Collier (1986) realised that involving the subjects of the research in the research process through photographs helped to build rapport and a more collaborative approach, especially when dealing with uncomfortable issues. He also realised that photographs helped to structure the interview and prompted the interviewee to be open about difficult subjects. In particular, he found that using photographs helped to stimulate memories. Harper (1998: 35) also pointed to these two advantages of using photographs in an interview process. Photographs helped to build a collaborative approach and were particularly useful in stimulating feelings and memories in the interviewee.

It was clear therefore to the researcher that photo-elicitation would be a suitable methodology to find out more about what people felt about gentrification. The researcher identified individuals that she had met during the first two stages of the project. These individuals consisted mainly of working-class residents and community leads, who originated from the Black Sea region of Turkey. In addition, the researcher identified middle-class residents, who were living in the new luxury apartments. She conducted a series of semi-structured interviews with these participants, using a set of fourteen photographs of the area undergoing gentrification taken during 'stage 2 ' of the project.

Prior to conducting the interviews, the researcher developed an information sheet and consent form. The information sheet set out the purpose of the research, how the information would be kept and stored and addressed issues around anonymity. For this stage of the research, the researcher needed to record the interviews and so required the formal consent of the participants. The researcher selected fourteen images for the photo-elicitation exercise which addressed a range of issues. The photographs showed where people lived, shopped and worked and provided information on the culture of the working-class residents. The researcher acknowledged that she had some assumptions going into this exercise. Her basic assumption in interviewing the Black Sea residents, based on earlier interactions, was that they would have 
some concerns or doubts about the changes that were taking place. Her assumption about the middle-class residents was that broadly they would be in favour of the way the area was being developed. Whilst acknowledging these assumptions and the subjective nature of the images selected, the researcher aimed to keep the interviews as open as possible, allowing the interviewees as much scope as possible to express their thoughts and feelings. The researcher developed an outline structure for the interviews, numbering each photograph, and developed a series of open questions to stimulate discussion. She fully recognised the collaborative nature of semi-structured interviews: "(...) meanings and understandings are created in interaction, which is effectively a co-production, involving researcher and interviewees" (Mason, 2002: 63). The interviews were conducted over a period of four weeks.

The researcher analysed the data generated by the interviews by listening back to the recorded interviews and identifying recurrent themes. She realised that the responses from the interviewees contained different types of data. The interviewees made observations about the images which included information about, for example, local history as well as social, cultural and economic life. These observations sometimes included also an emotional response to the images and ranged across time, looking back to what used to be, what is now and what may be in the future. The respondents provided insights into the process of gentrification through their observations and gave the researcher an understanding of the impact on their lives of this process through their emotional responses. The researcher therefore analysed the responses to the images initially from these two perspectives, identifying the different and recurrent observations made by the interviewees and the strength and frequency of different emotional responses. One other prism through which the researcher viewed the transcripts was by comparing the responses of the interviewees from the different communities.

Several images prompted strong feelings of nostalgia amongst the longterm residents of the area. The image in Figure 3 for example provoked a strong emotional response as interviewees reminisced about a time when the river was clean and full of fish. One respondent said that as child he used to swim and fish in the river and another reminisced about a farmer who kept goats along the river. It was clear from the long-term residents that the river used to be an extremely important and cherished feature of local life. Thoughts and emotions about the past were followed by observations about the current state of the river and how polluted it was. Some offered an explanation as to how the river had become so polluted. The new middle-class residents had of course a very different reaction to this image, as it had no past associations for them. One interviewee was unaware that there was a river nearby and was shocked to discover that there was. The middle-class residents also focused on environmental concerns but with no understanding of how the river had become polluted. One interviewee expressed a concern about potential flooding. 


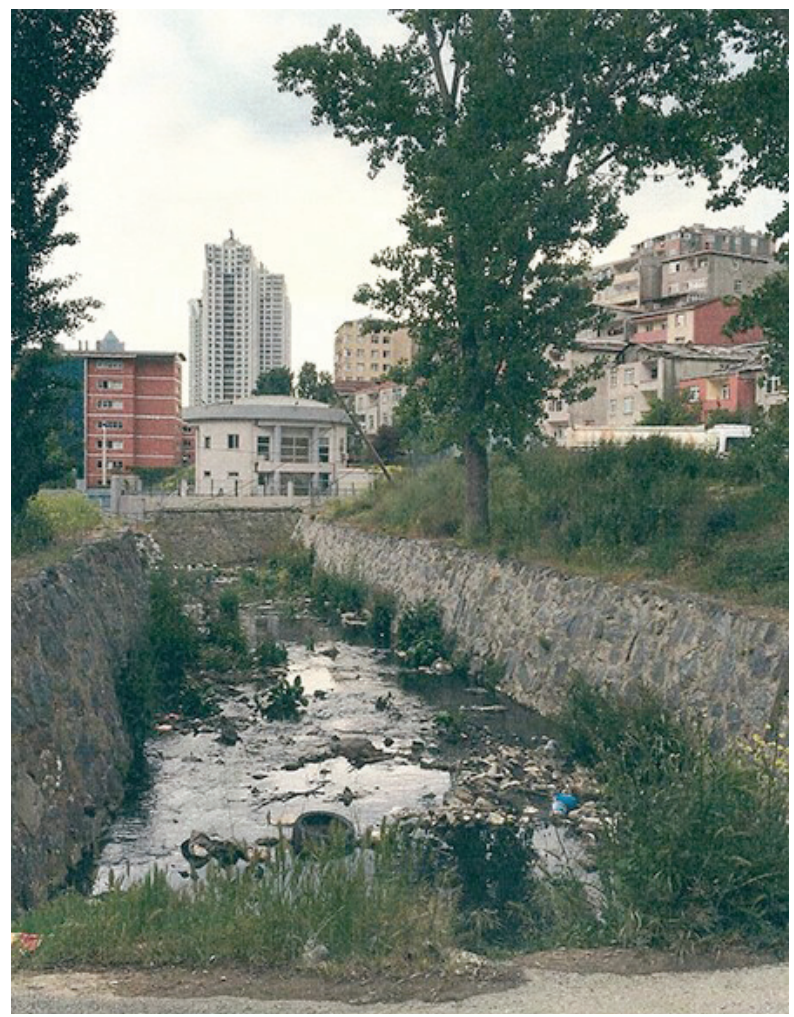

Figure 3

The long-term residents of Black Sea origin expressed remarkably consistent views about what was important to them and the way they would like to live. More than anything else, they kept on returning to the themes of community and culture. Images that showed shops for example prompted them to comment on how local shop keepers knew everyone, would still serve them even if they had no money and would open late at night if asked to do so. The image in Figure 4 also prompted observations about culture and community. One interviewee commented on how residents who grew vegetables would often give them to neighbours who needed them. He spoke about how growing vegetables was central to the culture of the Black Sea region where they had all originated from. This image provoked a very different response of course from the middle-class residents who saw a badly maintained piece of land next to a building that looked like a shack. The image in Figure 5 surprised all the respondents, both the long-term residents of Black Sea origin and the newly arrived middle-classes. The long-term residents saw this as an ideal of how they would like to live. It reminded them of how many people used to live before the process of gentrification had started and they were surprised, though happy, to see that it still existed. They felt that this represented a good and healthy way to live, close to nature. One respondent contrasted 
this image with the image in Figure 1 where people live on top of each other but have no sense of living in a community. The middle-class residents also thought that this image represented something appealing, commenting on its peaceful quality, but were surprised to discover that it was situated very close to them. This points to a critical difference in the outlook of the different communities. The long-term residents wanted to retain a form of village life on the fringes of the city, with its own individual characteristics and features, whereas the new residents had an entirely different concept of what constituted city life and were happy with their locality being absorbed into the wider city.

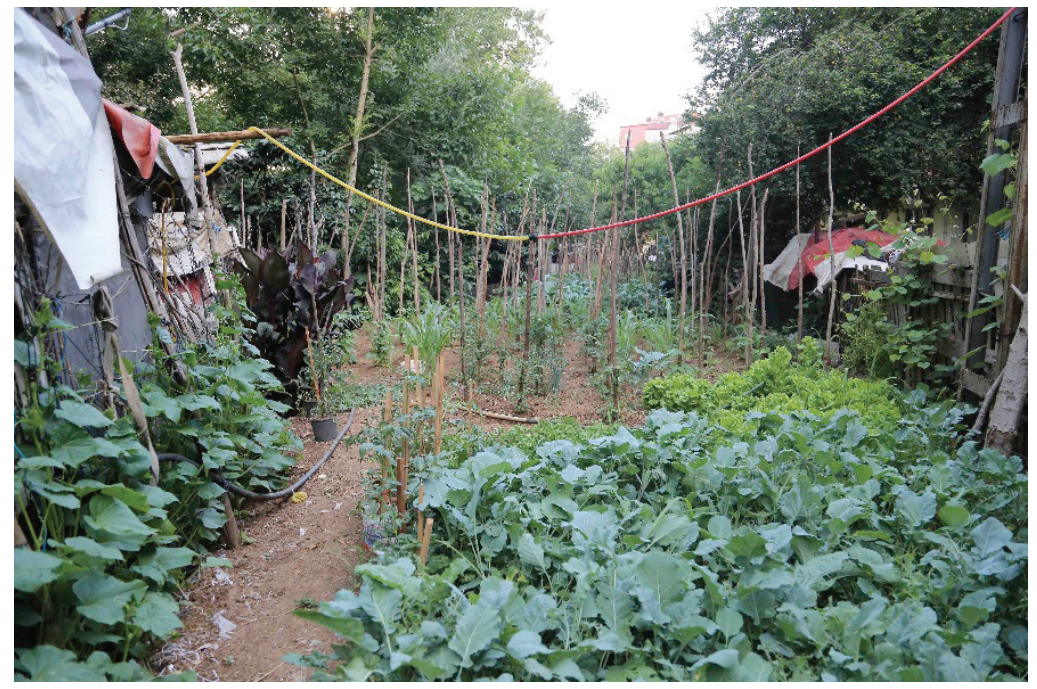

Figure 4

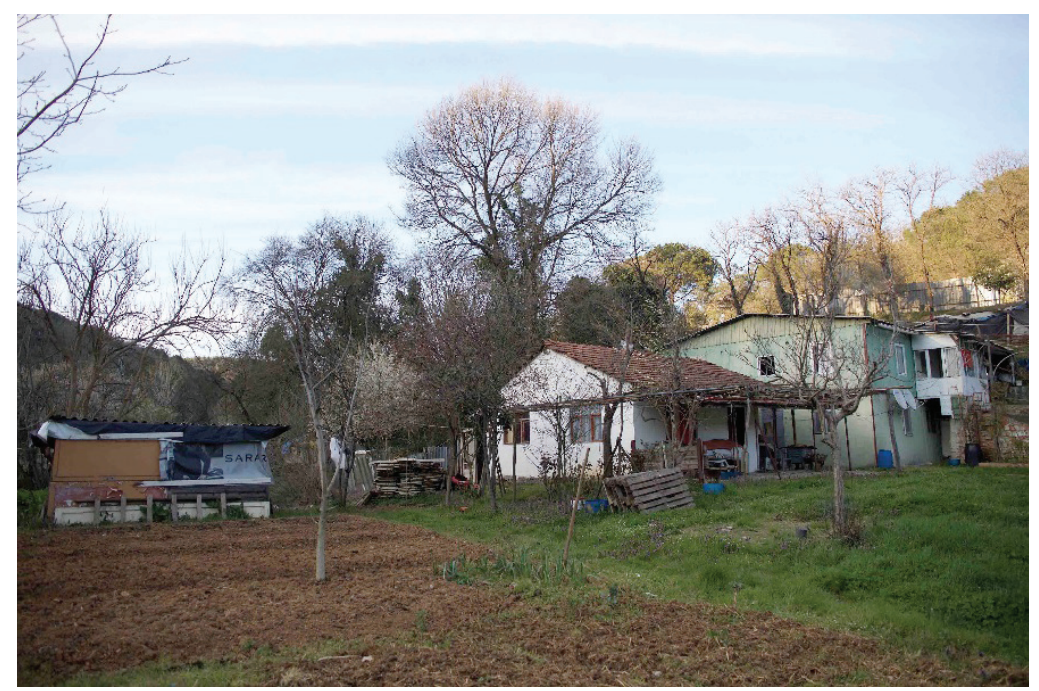

Figure 5 
All the respondents, both the long-term residents and the newly arrived middle class residents, provided insights into the process of gentrification whilst commenting on the images. Both groups confirmed that there was no interaction between the two communities, even though they lived in the same place within metres of each other. The middle-class residents had never entered, for example, the shops or markets that were used by the Black Sea residents. The respondents of both communities commented on the fact that the new buildings were designated as being in a different part of Istanbul to the squatter settlements, even though the new building were within the same locality. The middle-class residents referred to the promotion of those apartments that did not overlook the original town but instead looked towards the city. Everything was done to highlight the proximity to the nearby financial and business districts and downplay the existence of the original town. Both communities also commented on the building of a road which enabled the middle-class residents to enter the area where they lived without going through the squatter settlement. One community leader from the Black Sea region referred to open meetings where the developers highlighted the benefits that would arise for the local population from the development of the area, including better facilities and higher quality accommodation. He noted that there was no opportunity to ask any questions. This reflected a wider view that the original residents had very little say over how the area was being developed. This lack of involvement increased the level of anxiety about the future. The primary concern of the residents related to the social impact of the gentrification process and the loss of a sense of community. In addition, there were very practical concerns around the potential displacement of people. For local business people, there were concerns over how they would in future make their living.

The photo-elicitation process uncovered a range of emotions. The strongest and most frequently expressed emotion during the interviews with the long-term residents was nostalgia and sadness for a way of life that was disappearing. The main features of this way of life were community spirit and an affinity with nature. This emotion sometimes changed into expressions of resentment or anger. The image in Figure 1 for example prompted resentment at the speed and scale of the change and the impact this was having on their way of life. There was a view that there had been little consultation with the community over the development of the area. Respondents felt that economic drivers had been paramount and that social and other factors were not considered. Although respondents did express resentment, this feeling was lessened to an extent by a recognition that things could not be as they were before and that changes were inevitable. One other emotion that flowed from nostalgia about the past was concern about the future. It was clear that the residents were unsure about what this all meant for the future. The middle-class residents did not react with such strong emotions though the images did prompt some feelings of concern for the resident population. They also

\section{0 | ETKíleşim | Yıl2|Sayı 3| Nisan 2019}


expressed concerns about pollution and environmental damage and in this respect responded in a similar way to the long-term residents.

\section{Summary of Findings and Conclusion}

There is a type of gentrification currently taking place in Istanbul which involves the building of luxury apartment blocks on land once occupied by squatter communities. This research project, through focusing on one district, has identified some important aspects of this process. In the area that forms the basis of this study, the scale of the gentrification process is quite staggering. The character and social profile of the area is being transformed through the building of apartment blocks and the influx of new middle-class residents. The researcher found evidence of significant social barriers between the communities, with little or no interaction between them. The major driver behind the process of gentrification is economic, with a demand for property close to the financial and business districts of Istanbul. Some of the long-term residents had done well financially from this process as land they owned had been bought by the developers. Some had been able to buy new apartments but, wherever possible, they preferred to remain in their original squatter homes. Others, especially those who rent properties, faced an uncertain future. There appeared to be a lack of consultation about how the development of the area should proceed which has led to frustration about the process. This failure to engage the local population in the process can lead to resentment. Uzun (2003: 373) makes a similar observation about his case study in Ankara, that there was a failure to construct an organisation that would inform, persuade and motivate people and enable their participation.

It was clear from the research that despite the investment in the area, including the building of roads, there were concerns about the potential negative impact on the local community. Whilst recognising the economic benefits, long-term residents were deeply concerned by the profound social impact of the development and the consequences it might have on community relations. It was clear that the new middle-class arrivals and the long-term residents held different concepts about the type of life they wished to lead and what it means to live in a city. There were some indications that the communities could find some common ground, especially around pollution and the environment.

Photography has been integral to this research project. The photographs in 'stages 1 and 2' highlighted the nature of the gentrification process, the extraordinary contrasts between the old and the new. They helped to give a sense of how the long-term residents might have felt and therefore suggested possible avenues of further research and enquiry, which were explored in the photo-elicitation stage. The qualitative research conducted during the photo-elicitation stage has generated findings that would not be possible 
through more conventional social science research methodologies. By using photographs in the interviews, the researcher has been able to generate insights into how people feel about the process of gentrification. It is unlikely that standard interviews would have been able to generate the same quality of response. As Harper (1998) pointed out, photographs help to stimulate memories and feelings in the interviewee. As gentrification can have such profound, life-changing consequences, it is important to understand how people who are affected by it really feel. What this study shows is that ultimately what matters to people is a sense of well-being and identity, which is linked to their values and culture and the connections they have within their community.

\section{References}

Davidson, M. and Lees, L. (2005). "New-Build "Gentrification" and London's Riverside Renaissance". Environment and Planning A. 37(6). 1015-1032.

Fairclough, C. M. (2017). "A City Transformed: Visualising the Social Effects of Gentrification in One District of Istanbul". C. Cinar and M. S. Akim (eds.) International Interdisciplinarity in the Arts Symposiums 1: Cinema/Photography, Book of Proceedings. (32-44). Istanbul, Turkey: Cinius.

(2018). "The Value of Photography as a Methodology within the Social Sciences". Etkileşim. 1(2). 108-123.

Glass, R. (1964). "Introduction: Aspects of Change”. Centre for Urban Studies (ed.) London: Aspects of Change. London: MacKibbon and Kee.

Hammersley, M. and Atkinson, P. (1995). Ethnography Principles in Practice. London: Routledge.

Harper, D. (1998). "An Argument for Visual Sociology". Prosser, J. (ed.) Image-Based Research. Padstow: TJ International Ltd.

(2012). Visual Sociology. Abingdon: Routledge.

Islam, T. (2005). "Outside the Core: Gentrification in Istanbul". Atkinson, R. and Bridge, G. (ed.) Gentrification in a Global Context: The New Urban Colonialism. Taylor \& Francis e-Library.

Lees, L., Slater, T., Wyly, E. (2008). Gentrification. New York: Routledge.

Mason, J. (2002). Qualitative Researching. London: SAGE Publications.

Pink, S. (2013). Doing Visual Ethnography. London: SAGE Publications.

Prosser, P. and Schwartz, D. (1998). "Photographs within the Sociological Research Process". Prosser, J. (ed) Image-Based Research. Padstow: T J International Ltd.

Rose, G. (2012). Visual Methodologies. London: SAGE Productions.

Smith, N. (1982). "Gentrification and Uneven Development". Economic Geography. 58(2). 139-155.

112 | ETKíleşim |Yıl2|Sayı 3 | Nisan 2019 
Suchar, C. (1997). "Grounding Visual Sociology Research in Shooting Scripts". Qualitative Sociology. 20(1). 33-55.

Uzun, C. Nil. (2003). "The Impact of Urban Renewal and Gentrification on Urban Fabric: Three Cases in Turkey". Tijdschrift voor Economische en Sociale Geografie. 94(3). 363-375. 